DOI: 10.32844/2222-5374-2020-104-2.49

УДК 343.162.4

Савицький O. A.,

здобувач Національної академії внутрішніх справ

\title{
ПОВНОВАЖЕННЯ СУДДІ ВИЩОГО АНТИКОРУПЦИЙНОГО СУДУ У КРИМІНАЛЬНОМУ ПРОВАДЖЕННІ
}

Стаття присвячена висвітленню деяких структурних елементів правового статусу судді Вищого антикорупційного суду у кримінальному процесі. На основі аналізу поглядів науковців визначено, що зміст правового статусу судді Вищого антикорупційного суду включає сукупність таких елементів як, функції (основні напрями кримінально-процесуальної діяльності), повноваження (права та обов'язки), гарантії діяльності та юридична відповідальність. Особливу увагу приділено питанню повноважень досліджуваного учасника кримінального провадження. З'ясовано, що суддя Вищого антикорупційного судує специфічною посадовою особою, представником суддівського корпусу, який у передбаченій законом процесуальній формі здійснює правосуддя в кримінальних провадженнях. Сфокусовано увагу на тому, що особливістю правого статусу судді Вищого антикорупційного суду є сфера реалізації прав та виконання обов'язків. Це обумовлене завданнями Вищого антикорупційного суду, які полягають у здійсненні правосуддя відповідно до визначених законом засад та процедур судочинства з метою захисту особи, суспільства та держави від корупційних і пов'язаних із ними кримінальних правопорушень та судового контролю за досудовим розслідуванням кримінальних правопорушень, дотриманням прав, свобод та інтересів осіб у таких кримінальних провадженнях. З'ясовано, що ні законодавство, ні правова доктрина не наводить системного визначення повноважень судді. Крім того законодавцем не закріплено у положеннях Кримінального процесуального кодексу коло специфічних прав та обов'язків саме для суддів Вищого антикорупційного суду. Визначено, що основним призначенням Вищого антикорупційного суду $\epsilon$ здійснення правосуддя у чітко визначеному переліку категорій справ, причиною виділення яких став саме неефективний їх розгляд у судах загальної юрисдикції та порушення розумних строків розгляду. В цьому сенсі запропоновано встановлення обов'язку для суддів Вищого антикорупційного суду дотримання конкретних строків судового розгляду кримінальних проваджень щодо корупційних кримінальних правопорушень. Запропоновано спектр процесуальних повноважень судді Вищого антикорупційного суду поділити на загальний (охоплює ознаки правового статусу, притаманні всім суддям у системі правосуддя) та спеціальний (спрямований на деталізацію та конкретизацію прав та обов'язків саме судді Вищого антикорупційного суду) блоки.

Ключові слова: процесуальний статус, повноваження, права та обов'язки, суддя, кримінальне провадження. 
Актуальність теми. Правовий статус судових органів зазнає постійних змін і трансформацій. Положення, які регламентують цей процес на кожному його етапі стають предметом наукових дискусій та досліджень. Предметом нашого дослідження є зміни, котрі відбулись у кримінальному процесуальному законодавстві, що пов'язані з появою особливого учасника кримінального провадження - судді Вищого антикорупційного суду (далі - ВАС). У зв'язку з цим актуальності набуває більш детальна розробка нових підходів до розуміння окремих питань правового статусу судді в кримінальному судочинстві. Спрямування діяльності суду на боротьбу з корупційною злочинністю, зміцнення демократичної соціально-правової держави та забезпечення верховенства права, додержання прав і основних свобод людини та громадянина є однією із засад державної політики в галузі прав людини.

Ефективність правосуддя під час розгляду кримінальних проваджень залежить як від того, наскільки точно і реально визначені його мета і завдання, так і від того, чи достатньо процесуальних та інших засобів для їх досягнення. Особливість статусу суддів має суттєвий вплив на здійснення справедливого правосуддя, саме тому вирішення питання про кримінально-процесуальні повноваження судді ВАС має не лише суто теоретичний інтерес, а й практичне значення, оскільки дає змогу визначити його специфічну кримінально-процесуальну діяльність та засоби її здійснення.

Мета статті. Власне, з'ясування повноважень судді ВАС у сфері здійснення судового контролю та правосуддя в кримінальному провадженні та способів і засобів їх реалізації і ставить своїм завданням стаття.

Аналіз останніх статей та публікацій. Дослідженням проблематики діяльності судді в кримінальному провадженні присвячені роботи Ю. М. Грошевого, В. Я. Корсуня, Л. М. Москвич, С. В. Подкопаева, С. В. Прилуцького, Н. З. Рогатинської, Л. О. Сергієнко, В. О. Сердюка. Ю. В. Скрипіної, Н. П. Сизої, О. С. Ткачука, А. Р. Туманянц, Л. Д. Удалової та інших учених. Праці цих науковців безумовно становлять значущий для теорії кримінального процесу комплекс уявлень про теоретичні основи процесуального статусу судді, історичний та порівняльний аспекти правового інституту слідчого судді, поняття, предмет та меж судового контролю в кримінальному процес тощо. Проте наукові дослідження щодо висвітлення системного аналізу процесуального статусу судді майже відсутні.

У контексті досліджуваного питання, на нашу думку, доцільно виокремити публікації науковців таких як І. Г. Бірюкова, В. В. Вапнярчук, I. В. Грицюк, Т. О. Ламбуцька, Т. Г. Оксюта, Г. В. Остафійчук, В. А. Селезньов та ін., які розглядають окремі аспекти процесуального статусу судді, в тому числі судді ВАС.

Виклад основного матеріалу. Правовий статус судді характеризує обсяг правових можливостей, певну міру свободи поведінки носія судової влади. За своєю сутністю він є спеціальним різновидом професійного статусу, оскільки йдеться про виняткові правові можливості посадової особи судової влади, якій надаються відповідні правові можливості для ефективного здійснення професійної діяльності [1, с. 12]. Вказані 
можливості, на думку С. В. Слінько, дозволяють забезпечити належне, об’єктивне, повне, неупереджене виконання функції судової влади, а саме: здійснення від імені держави контролю в механізмі поділу влади; реалізація правосуддя, визнання особи винною у вчиненні злочину шляхом постановлення вироку; здійснення інших функцій, реалізація яких, як переконує вчений, передбачає надання судді процесуальних повноважень, сукупність яких становить зміст правового статусу судді [2, с. 74-75].

Таким чином, характерною рисою правового статусу судді $є$ покладені на нього обов'язки та природа службових повноважень, специфіка діяльності органів, у яких вони служать. Тому не вступаючи у численні наукові дискусії щодо сутності поняття правового статусу, лише зазначимо, що в юридичній літературі під процесуальним статусом судді розуміють сукупність процесуальних прав, гарантій, обов'язків судді, спрямованих на реалізацію завдань провадження, а також юридичну відповідальність у передбачених законом випадках [3, с. 14].

Поділяючи та розвиваючи наведені точки зору у контексті наукової статті, вважаємо, що процесуальний статус судді ВАС охоплює встановлену нормами кримінального процесуального права сукупність таких елементів як, функції (основні напрями кримінально-процесуальної діяльності), повноваження (права та обов'язки), гарантії їх діяльності та юридична відповідальність. При цьому визначальним елементом правового статусу судді ВАС, на думку автора, виступають саме його повноваження.

В цьому контексті, необхідно зазначити, що під правовим становищем судді, в тому числі судді ВАС, слід розуміти систему його загальних, тобто, встановлених законами судоустрою, і спеціальних, передбачених процесуальними законами, повноважень. Залишаючи поза увагою загальні повноваження, в рамках дослідження вважаємо за доцільне розглянути повноваження посадових осіб, уповноважених на здійснення кримінального провадження. Саме вони реалізуються суддею ВАС у кримінальному провадженні за корупційними справами, і $\epsilon$, відповідно, засобами зв'язку між його учасниками.

Процесуальний статус судді насамперед закріплений у ст. 124 Конституції України, де передбачено, що основним напрямом діяльності суду є здійснення правосуддя [4].

Згідно з ст. 32. Закону України «Про судоустрій і статус суддів» повноваженнями вищого спеціалізованого суду є здійснення правосуддя як судом першої та апеляційної інстанції у справах та в порядку, визначених процесуальним законом [5].

Таким чином, можна говорити про те, що суддя ВАC $\epsilon$ специфічною посадовою особою, представником суддівського корпусу, який у передбаченій законом процесуальній формі здійснює правосуддя в кримінальних провадженнях щодо корупційних злочинів.

Грицюк I. В., Бірюкова I. Г., аналізуючи процесуальний статус судді Вищого антикорупційного суду у кримінальному провадженні, дійшли висновку, що досліджуваний суб'єкт є особливим учасником кримінального провадження та характеризується таким чином:

1) йому належить центральне місце в системі правового захисту конституційних та інших правових цінностей. Діяльність суддів становить уні- 
версальний механізм із захисту й охорони права, відновлення порушеного права, припинення порушеного права, розгляд справ у судовому засіданні;

2) публічність судової діяльності - сутність відкритості, політичної або партійної незаангажованості судів та суддів;

3) юрисдикційність судової діяльності у кримінальному провадженні за корупційними справами полягає в сукупності правомочностей суб'єктів цієї діяльності з розгляду та розв’язання цієї категорії справ [6].

Враховуючи позицію науковців, зазначимо, що процесуальний статус судді ВАС у кримінальному провадженні варто розкривати саме в кореляції 3 визначенням його повноважень, спектр яких доцільно поділити на загальний та спеціальний блоки. Загальний блок встановлює ознаки правового статусу, притаманні всім суддям у системі правосуддя.

Власне, чинне законодавство не містить спеціальної норми, що закріплює права та обов'язки суддів ВАС, що в повній мірі узгоджується з нормами Закону України «Про судоустрій і статус суддів», де у ч. 2 ст. 52, де передбачено, що судді в Україні мають єдиний статус незалежно від місця суду в системі судоустрою чи адміністративної посади, яку суддя обіймає в суді. Разом з тим, згідно ст. 1 Закону України «Про Вищий антикорупційний суд» Вищий антикорупційний суд є постійно діючим вищим спеціалізованим судом у системі судоустрою України. Відтак, судді ВАС наділені усіма правами та на них покладено виконання усіх обов'язків, що передбачені Законом України «Про судоустрій і статус суддів».

Окрім цього, блок загальних повноважень судді регламентується Кримінальним процесуальним кодексом України.

Загалом норми кримінального процесуального законодавства містять чималу кількість повноважень судді в залежності від функцій, які він реалізовує; стадії кримінального процесу; сфери, в якій він здійснює кримінальну процесуальну діяльність (повноваження, пов'язані 3 міжнародним співробітництвом; повноваження із забезпечення законності та обгрунтованості застосування заходів кримінально-процесуального примусу; повноваження із забезпечення доказів у кримінальному провадженні) та ін. Навіть розглядаючи окрему сферу кримінальнопроцесуальної діяльності судді не можна не звернути увагу на їх надмірну розпорошеність у тексті КПК України.

На думку Г. В. Остафійчук, кримінальний процесуальний закон установлює судові повноваження, що містять такі елементи: прийняття процесуальних рішень, які $\epsilon$ обов'язковими для виконання всіма посадовими особами, а також окремими громадянами; забезпечення виконання правових рішень заходами державного переконання; матеріальне забезпечення нормативно-правових рішень; ухвалення вироку [7, с. 117].

Натомість спеціальний спектр повноважень передусім регламентується Законом України «Про Вищий антикорупційний суд» і спрямований на деталізацію та конкретизацію ролі саме судді Вищого антикорупційного суду, виходячи з того, що основним завданням ВАС $\epsilon$ здійснення правосуддя у чітко визначеному переліку справ, причиною виділення яких став неефективний їх розгляд у судах загальної юрисдикції та порушення розумних строків розгляду. 
Покликання ВАС полягає в здійсненні справедливого правосуддя в кримінальних провадженнях щодо корупційних злочинів. У зв'язку з цим відповідно до Закону України «Про Вищий антикорупційний суд» суд уповноважений здійснювати правосуддя як суд першої та апеляційної інстанцій у кримінальних провадженнях щодо кримінальних правопорушень, віднесених до його юрисдикції (підсудності) процесуальним законом, а також шляхом здійснення у випадках та порядку, визначених процесуальним законом, судового контролю за дотриманням прав, свобод та інтересів осіб у таких кримінальних провадженнях [8].

3 огляду на викладене, судді ВАС, здійснюючи функції як правосуддя так і інші функції, які виконуються у різних стадіях кримінального провадження, щодо, так би мовити, обмеженої кількості кримінальних проваджень та визначеного кола кримінальних правопорушень наділені широкими повноваженнями, передбаченими кримінальним процесуальним законодавством, щодо:

- розгляду слідчими суддями клопотань, скарг, заяв під час досудового розслідування;

- здійснення оцінки законності і правомірності проведених детективами Національного антикорупційного бюро України та прокурорамиСпеціалізованоїантикорупційноїпрокуратурипроцесуальних дій і прийнятих саме ними процесуальних рішень;

- прийняття рішень, пов'язаних з підготовкою і призначенням справи до головного судового розгляду;

- розгляду кримінальних проваджень у першій інстанції;

- розгляду справ в апеляційному та касаційному порядку;

- перегляду судових рішень, що набрали законної сили;

- звернення судового рішення до виконання; мості;

- розгляду питань, що виникають при виконанні вироку, зняття суди-

- розгляду заяв про відновлення втрачених матеріалів кримінального провадження; тощо.

- розгляду справ в порядку надання міжнародної правової допомоги

Підсумовуючи, необхідно зазначити, що специфічними рисами процесуального статусу судді ВАС у кримінальному провадженні $\epsilon$ :

По-перше, це сфера реалізації прав та виконання обов'язків вказаного суб’єкта кримінального провадження. Це обумовлене завданнями ВАС, які полягаютьу здійсненні правосуддя відповідно до визначенихзаконом засад та процедур судочинства з метою захисту особи, суспільства та держави від корупційних і пов'язаних із ними кримінальних правопорушень та судового контролю за досудовим розслідуванням цих кримінальних правопорушень, дотриманням прав, свобод та інтересів осіб у кримінальному провадженні.

По-друге, з урахуванням викладеного, необхідно констатувати, що під час розгляду справ судді ВАС керуються положеннями Кримінального процесуального кодексу, а не якимсь особливим «антикорупційним законодавством, що встановлює особливий порядок здійснення правосуддя», процедура розгляду є такою ж, як і в інших судах, а на його суддів поширюється дія Закону України «Про судоустрій та статус суддів». 
BAC $є$ складовою судової системи України, тому на наше переконання, права та обов'язки досліджуваного суб'єкта слід розглядати в системі правого статусу суддів України.

Крім того, законодавцем не закріплено у положеннях Кримінального процесуального кодексу коло специфічних прав та обов'язків для суддів BAC. Разом з тим основним завданням ВАС $є$ здійснення правосуддя у чітко визначеному переліку категорій справ, причиною виділення яких став саме неефективний їх розгляд у судах загальної юрисдикції та порушення розумних строків розгляду. В цьому сенсі доцільним $\epsilon$ встановлення обов'язку для суддів ВАС дотримання конкретних строків судового розгляду кримінальних проваджень щодо корупційних кримінальних правопорушень.

\section{СПИСОК ВИКОРИСТАНИХ ДЖЕРЕЛ:}

1. Москвич Л. М., Подкопаєв С. В., Прилуцький С. В. Статус судді: питання теорії та практики: Монографія. Х.: ВД «ІНЖЕК», 2004. 360 с.

2. Слінько С В. Концепція незалежності судової влади: функція та елементи. Вісник Харківського національного університету внутрішніх справ. 2011. № 4. С. 73-79.

3. Собовий О. М. Правовий статус судді в адміністративно-деліктному провадженні : автореф. дис. на здобуття наук. ступеня канд. юрид. наук. спец. 12.00.07. Київ, 2010. 20 с.

4. Конституція України від 28 червня 1996 року № 254к/96-ВР. Відомості Верховної Ради України. 1996. № 30. ст. 141. URL: https://zakon. rada.gov.ua/laws/show/254\%D0\%BA/96-\%D0\%B2\%D1\%80.

5. Про судоустрій і статус суддів: Закон України від 2 червня 2016 р. 1402-VIII. Відомості Верховної Ради. 2016. № 31. ст. 545. URL: https://zakon. rada.gov.ua/laws/show/1402-19.

6. Грицюк I. В., Бірюкова I. Г. Процесуальний статус судді Вищого антикорупційного суду у кримінальному провадженні. Ірпінський юридичний часопис: науковий журнал. 2019. Вип. 2. С. 129-136.

7. Остафійчук Г. В. Процесуальні функції судді у кримінальному провадженні. Публічне право. № 1 (13). 2014. С. 114-120.

8. Про Вищий антикорупційний суд: Закон України від 07 червня 2018 р. № 2447-VIII. Відомості Верховної Ради. 2018. № 24. ст.212. URL: https://zakon.rada.gov.ua/laws/show/2447-19\#Text.

\section{o. Savytskyi}

\section{POWERS OF A JUDGE OF THE HIGHER ANTI-CORRUPTION COURT IN CRIMINAL PROCEEDINGS}

The article is devoted to the coverage of some structural elements of the procedural status of a judge of the Higher Anti-Corruption Court in criminal proceedings. Based on the analysis of scholars' views, it was determined that the content of the procedural status of a judge of the Higher Anti-Corruption Court includes a set of elements such as functions (main areas of criminal procedure), powers (rights and responsibilities), guarantees and legal liability. Particular attention is paid to 
the question of the powers of the investigated participant in criminal proceedings. It was found out that the judge of the Higher Anti-Corruption Court is a specific official, a representative of the judiciary, who administers justice in criminal proceedings in the procedural form provided by law. The peculiarity of the legal status of a judge of the Higher Anti-Corruption Court is the sphere of realization of rights and performance of duties. This is connected to the tasks of the Higher Anti-Corruption Court, which are to administer justice in accordance with the statutory principles and procedures of justice to protect individuals, society and the state from corruption and related criminal offenses and judicial control over the pre-trial investigation of criminal offenses. It was found that neither the law nor the legal doctrine provide for a systematic definition of a judge's authority. In addition, the legislator does not enshrine in the provisions of the Code of Criminal Procedure a number of specific rights and responsibilities for judges of the Higher Anti-Corruption Court. It is determined that the main purpose of the Higher Anti-Corruption Court is to administer justice according to a clearly defined list of categories of cases, the reason for which was their ineffective consideration in courts of general jurisdiction and violation of reasonable time limits. In this sense, it is proposed to establish the obligation of judges of the Higher Anti-Corruption Court to adhere to specific deadlines for consideration of criminal proceedings for corruption offenses. It is proposed to divide the range of procedural powers of a judge of Higher Anti-Corruption Court judge into general (covers the features of legal status inherent in all judges in the justice system) and special (aimed at detailing and specifying the rights and responsibilities of a judge of the Higher Anti-Corruption Court).

Keywords: procedural status, powers, rights and responsibilities, judge, criminal proceedings. 